\title{
Amplification of 1-amino-cyclopropane-1-carboxylic (ACC) deaminase from plant growth promoting rhizobacteria in Striga-infested soil
}

\author{
Olubukola O. Babalola ${ }^{1,2^{*}}$, Ellie O. Osir ${ }^{2}$, Abiodun I. Sanni ${ }^{1}$, George D. Odhiambo ${ }^{3}$, and \\ Wallace D. Bulimo ${ }^{2, \psi}$ \\ 1 Department of Botany and Microbiology, University of Ibadan, Ibadan, Nigeria \\ ${ }^{2}$ International Centre of Insect Physiology and Ecology, Nairobi, Kenya \\ ${ }^{3}$ Kenya Sugar Research Foundation, Kisumu, Kenya.
}

Accepted 28 May 2003

\begin{abstract}
Experiments were conducted in pots to determine the growth effect of different rhizobacteria on maize under Striga hermonthica infestation. Three bacteria were selected based on their plant growth promoting effects. Whole bacterial cells of the rhizobacteria were used to amplify 1-aminocyclopropane-1-carboxylic acid (ACC) deaminase gene by polymerase chain reaction (PCR). Each bacterial inoculation increased agronomic characteristics of maize although not always to a statistically significant extent. The extent of growth enhancement differs between the isolates. Enterobacter sakazakii 8MR5 had the ability to stimulate plant growth, however in the PCR study, ACC deaminase was not amplified from this isolate, indicating that not all plant growth-promoting rhizobacteria contain the enzyme ACC deaminase. In contrast, an ACC deaminase specific product was amplified from Pseudomonas sp. 4MKS8 and Klebsiella oxytoca 10MKR7. This is the first report of ACC deaminase in K. oxytoca.
\end{abstract}

Key words: 1-amino-cyclopropane-1-carboxylic acid, ACC deaminase, PCR, rhizobacteria, Striga hermonthica.

\section{INTRODUCTION}

Gressel (2000) has recently made a call for new concepts of using molecular biology for weed control that do not necessarily utilize herbicide-resistant crops. For the obligate parasitic weed Striga hermonthica microorganisms are being considered for biological control (Abbasher and Sauerborn, 1992; Savard et al., 1997; Berner et al., 1999; Marley et al., 1999)

A way that plant growth-promoting rhizobacteria (PGPR) stimulate plant growth is through the activity of the enzyme 1-amino-cyclopropane-1-carboxylic (ACC) deaminase (Glick et al., 1998), which causes a lowering of plant ethylene levels resulting in longer roots. However, the role of ACC deaminase in the root colonising bacteria is unknown (Wang et al., 2000). ACC deaminase from bacteria, Pseudomonas sp. ACP (Sheehy et al., 1991), Pseudomonas putida and Pseudomonas fluorescens (Glick et al., 1995), Enterobacter cloacae CAL2 and UW4 (Shah et al., 1998),

${ }^{*}$ Corresponding author: Tel: 234-803-703-5965; e-mail: olubukola_babalola@hotmail.com

\footnotetext{
${ }^{\Psi}$ Present address: Department of Biochemistry, University of Nairobi, Nairobi, Kenya.
}

Kluyvera ascorbata SUD165 (Burd et al., 1998), and yeast, Hansenula saturnus (Honma and Shimomura, 1978), and fungus, Penicillium citrinum (Jia et al., 2000) have been reported. However, work in this area represents only plant-microbe interaction. In this regard, we examined Striga-infested plant microbe interaction.

In an effort to identify PGPR in a shorter number of days as compared to several months of screenhouse trials, we have used polymerase chain reaction (PCR) to amplify ACC deaminase gene from isolates previously examined in the screenhouse. In this regard, we chose PCR for this study because we see the need for reevaluation of our previous random amplified polymorphic DNA study (Babalola et al., 2002b) with gene-specific primers targeted toward bacterial ACC deaminases. PCR technique is simple, repeatable and sensitive and can be used for phylogenetic and diagnostic analyses.

\section{RESULTS AND DISCUSSION}

The bacteria increased plant height, root dry weight, and Striga fresh weight although not always to a statistically significant extent. Bacterial inoculation significantly increased number of leaves (Table 1). One of the 
Table 1. Effect of seed treatment with 8 bacterial isolates on the agronomic characteristics of a susceptible maize hybrid (H511) in screenhouse (mean \pm std error).

\begin{tabular}{|l|c|c|c|c|c|}
\hline Bacterial treatments $^{*}$ & $\begin{array}{l}\text { Plant height } \\
(\mathrm{cm})\end{array}$ & $\begin{array}{l}\text { Root dry } \\
\text { weight }(\mathrm{g})\end{array}$ & $\begin{array}{l}\text { Stover dry } \\
\text { weight }(\mathrm{g})\end{array}$ & $\begin{array}{l}\text { Number of } \\
\text { leaves }\end{array}$ & $\begin{array}{l}\text { Striga fresh } \\
\text { weight (g) }\end{array}$ \\
\hline Uninoculated control & $65.3 \pm 1.8$ & $3.6 \pm 0.2$ & $6.4 \pm 0.8$ & $7.7 \pm 0.1$ & $1.5 \pm 0.4$ \\
8MR5 & $67.8 \pm 1.8$ & $4.0 \pm 0.4$ & $6.2 \pm 0.5$ & $7.9 \pm 0.1$ & $1.8 \pm 0.7$ \\
4MKS8 & $68.6 \pm 1.7$ & $3.9 \pm 0.4$ & $6.4 \pm 0.6$ & $8.2 \pm 0.1$ & $2.0 \pm 0.6$ \\
10MKR7 & $67.6 \pm 1.2$ & $3.9 \pm 0.2$ & $7.5 \pm 0.7$ & $7.9 \pm 0.2$ & $0.9 \pm 0.3$ \\
8MR5+4MKS8 & $66.5 \pm 2.3$ & $4.1 \pm 0.5$ & $6.8 \pm 0.7$ & $7.9 \pm 0.2$ & $1.6 \pm 0.5$ \\
8MR5+10MKR7 & $63.5 \pm 3.6$ & $3.8 \pm 0.3$ & $7.0 \pm 0.7$ & $7.9 \pm 0.2$ & $1.7 \pm 0.7$ \\
4MKS8+10MKR7 & $69.6 \pm 1.7$ & $4.4 \pm 0.3$ & $7.6 \pm 0.6$ & $8.0 \pm 0.1$ & $1.2 \pm 0.5$ \\
8MR5+4MKS8+10MKR7 & $69.6 \pm 2.1$ & $4.4 \pm 0.5$ & $8.1 \pm 1.0$ & $8.1 \pm 0.1$ & $2.3 \pm 0.8$ \\
& & & & & 0.19 \\
LSD (0.05) & 2.98 & 0.45 & 0.99 & & 0.72 \\
\hline
\end{tabular}

"8MR5 = E. sakazakii, 4MKS8 = Pseudomonas sp., 10MKR7 = K. oxytoca

Studies were conducted on screenhouse benches at Kenya Sugar Research Foundation from January to June 2001. Clean Striga free pots (10 $x 10 \mathrm{x}$ $14 \mathrm{~cm}$ ) containing approximately $1 \mathrm{~kg}$ soil were filled with the experimental soil. S. hermonthica collected from Kibos during the long rains of year 2000 , was used to conduct the experiment. The experimental soil was infested with $S$. hermonthica at a rate of approximately 1000 seeds/pot and left to precondition for 14 days. Bacterial suspensions $\left(1.5 \mathrm{ml}\right.$ of $\left.1.4 \times 10^{6} \mathrm{cfu} \mathrm{ml}^{-1}\right)$ were inoculated into maize planting holes as follows: (1) no bacterial cells, (2) 8 MR5 only, (3) 4MKS8 only, (4) 10MKR7 only, (5) 8MR5 + 4MKS8, (6) 8MR5 + 10MKR7, (7) 4MKS8 + 10MKR7, and (8) 8MR5 + 4MKS8 + 10MKR7. Maize seed were sown three to a pot at a depth of $1.5 \mathrm{~cm}$ and thinned to one plant per pot at 7 days after planting. Pots were watered twice daily with tap water within the retention capacity of the pot. If soils are very dry introduced bacteria die rapidly (Chen and Alexander, 1973; Moffett et al., 1983). The potted soils were re-inoculated consecutively for the first 3 weeks on a weekly basis with $1.5 \mathrm{ml} \mathrm{of} 1.4 \times 10^{6} \mathrm{cfu} \mathrm{ml^{-1 }}$ bacterial inoculum, except for those pots that served as the control. The factorial experiment was laid out in completely randomized design (CRD) and repeated four times with five replicates per treatment on each occasion. Data were collected on plant height, root dry weight, stover dry weight (above-ground portion of seedling), number of leaves and Striga fresh weight.

important factors in bacteria application method is the bacterium in question as the extent of growth enhancement differs between the isolates. Several factors could be responsible for the unpredictable performance of the isolates in combination. Among such factors is competition among the introduced isolates, each of which is likely to have a different biotic potential. Hoffmann (1996) who worked on Fusarium nygamai for the biological control of Striga hermonthica in maize also found an improvement in maize vigour, grain and biomass yield. However, in the study any differences were not statistically significant. The present work clearly indicated that the rhizobacteria employed are plant growth promoters. They relieve a portion of the growth retardation caused by the parasitic infestation of $S$. hermonthica.

In this study, degenerate gene-specific primers targeted toward the microbial enzyme, 1aminocyclopropane-1-carboxylic acid (ACC) deaminase, were used to amplify the gene from three rhizobacteria species. It was observed that not all the isolates expressed ACC deaminase gene, however, all the three bacteria are PGPR (Table 1). Amplification products were observed only for Pseudomonas sp. 4MKS8 and K. oxytoca 10MKR7 (Figure 1). This result substantiates earlier reports that the rhizobacteria could find a place in integrated Striga management practices (Babalola et al., 2002a). Only fragments of $0.73 \mathrm{~kb}$ as expected were amplified, indicating that the PCR is specific and does not non-specifically amplify other genes. Identification was based on the size of the amplified product visualized on agarose gels. The fragment weighing $0.73 \mathrm{~kb}$ is of interest because the ACC-specified primers were expected to amplify a product of $0.73 \mathrm{~kb}$ (Figure 1).

Previous work showed that the enzyme, ACC, which controls ethylene production also causes Striga seeds to germinate (Logan and Stewart, 1991). Since all the three isolates produced detectable amounts of ethylene (OO Babalola, B Torto, and AI Sanni 2002, unpublished data), it was evident in this study that the presence of ACC deaminase gene in a bacterium does not have a direct influence on ethylene production. This is in agreement with the fact that bacteria do not synthesize ethylene via ACC (Fukuda et al., 1993). Besides, Sato et al. (1987) reported that $P$. syringae pv. glycinea also produce ethylene via a pathway that is different from the methionine-ACC pathway in higher plants. However, ACC deaminase has been found only in microorganism (Penrose and Glick, 1997). ACC deaminase catalyses the hydrolytic cleaveage of ACC, the immediate precursor of ethylene. The ACC deaminase gene could be exploited as a genetic marker to identify particular 


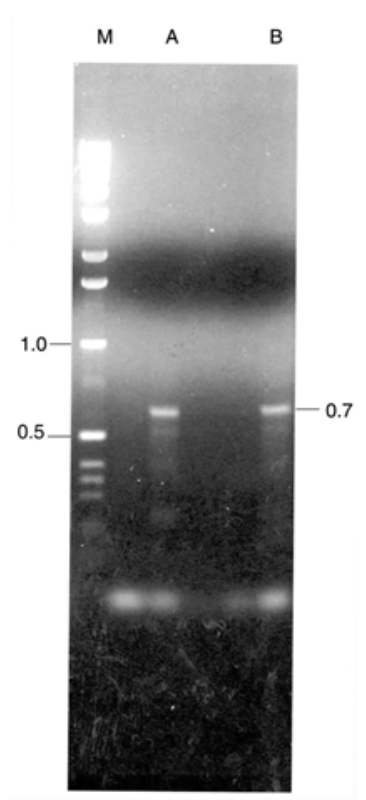

Figure 1. Amplification of the bacterial ACC deaminase gene of two bacteria species. PCR reactions were carried out in a total volume of $50 \mu \mathrm{l}$ using Taq polymerise (Amersham Life Science, Ohio, USA). $\mathrm{PCR}$ conditions was $2 \mathrm{~min}$ at $94^{\circ} \mathrm{C}, 1 \mathrm{~min}$ at $50^{\circ} \mathrm{C}, 1 \mathrm{~min}$ at $72^{\circ} \mathrm{C}$ for 30 cycles, followed by an additional $5 \mathrm{~min}$ at $72^{\circ} \mathrm{C}$ in a thermal cycler (MJ Research; Model PTC-100 ${ }^{\mathrm{TM}}$ ). Amplification products $(10 \mu \mathrm{l})$ were analysed on $1.5 \%$ agarose gels, detected by ethidium bromide staining and photographed under UV light. A 100 bp ladder DNA molecular marker XIV (Boehringer Mannheim, Germany) was used as the size markers (lane $M$ ). Lane $A$, Pseudomonas sp; lane B, K. oxytoca 10MKR7. Molecular weights are given in $\mathrm{kb}$.

strains of bacterial isolates of soil rhizosphere for use in Striga research. The genetic markers obtained in this manner should be useful to map and identify genes involved in ethylene formation. Alternatively, using molecular techniques, ethylene-producing bacteria that utilize the ACC deaminase pathway could be genetically modified to enhance the ACC deaminase production probably to improve plant growth. Enhanced ethylene production could also be a means to an end in the biological control of $S$. hermonthica through stimulation of Striga seed suicidal germination.

From screenhouse studies, Enterobacter sakazakii 8MR5 has the ability to stimulate plant growth, however in the PCR study, ACC deaminase was not amplified, indicating that not all PGPR contain the enzyme ACC deaminase. This result is in consonance with the report of Shah et al., 1997; Glick et al., 1998; and Shah et al., 1998. Shah et al., 1998 reported PGPR activity in strains belonging to the genus Enterobacter. They also suggested the possibility of the existence of several different types of ACC deaminase genes in different microbes, in which case ACC deaminase genes could have arisen by convergent evolution. Data presented in this manuscript are consistent with the findings of Shah et al., 1998. To the best of our knowledge, this is the first report of ACC deaminase in K. oxytoca. The use of soil bacteria as a biological strategy to control $S$. hermonthica is an attractive biocontrol approach, since enlisting nature's own agents and mechanisms to select for potential bacteria in the biological control of $S$. hermonthica would conserve the environment.

\section{ACKNOWLEDGEMENTS}

We wish to thank Dr D.K. Masiga and S.B. Obuya for comments on this work. This work was done while the first author holds a postgraduate fellowship of the Third World Organization for Women in Science. The use of facilities at the International Centre of Insect Physiology and Ecology (ICIPE), Nairobi, Kenya is gratefully acknowledged.

\section{REFERENCES}

Abbasher AA, Sauerborn J (1992). Fusarium nygamai, a potential bioherbicide for Striga hermonthica control in sorghum. Biol. Control 2:291-296.

Babalola OO, Osir EO, Sanni AI, Torto B, Odhiambo GD (2002a). Ethylene forming bacteria - a means to an end in Striga hermonthica control. In: Silvy $\mathrm{C}$ (ed) The role of genetics and evolution in biological control: Abstracts of the Global IOBC international symposium co-organized with C.I.L.B.A held at Agropolis international Montpellier, France. No 1, pp 3.

Babalola OO, Osir EO, Sanni Al (2002b). Characterization of potential ethylene-producing rhizosphere bacteria of Striga-infested maize and sorghum. Afr. J. Biotechnol. 1:67-69.

Berner DK, Schaad NW, Volksch B (1999). Use of ethylene-producing bacteria for stimulation of Striga spp. Seed germination. Biol. Control 15:274-282.

Burd GI, Dixon DG, Glick BR (1998). A plant growth-promoting bacterium that decreases nickel toxicity in seedlings. Appl. Environ. Microbiol. 64(10):3663-3668.

Chen M, Alexander M (1973). Survival of soil bacteria during prolonged desiccation. Soil Biol. Biochem. 5:213-221.

Fukuda H, Ogawa T, Tanase S (1993). Ethylene production by microorganisms. Adv. Microb. Physiol. 35:275-306.

Glick BR, Karaturovíc DM, Newell PC (1995). A novel procedure for rapid isolation of plant growth-promoting pseudomonads. Can. J. Microbiol. 41:533-536.

Glick BR, Penrose DM, Li J (1998). A model for the lowering of plant ethylene concentrations by plant growth-promoting bacteria. J. Theor. Biol. 190:63-68.

Gressel J (2000). Molecular biology of weed control. Transgenic Res. 9:355-382.

Hoffmann JH (1996). Striga hermonthica control with Fusarium nygamai in maize. In: Sauerborn J, Abbasher AA, Kroschel J, Cornes DW, Zoschke A, Hine KT, Moran VC (eds) Biological control of weeds: Proceedings of the $9^{\text {th }}$ international symposium held at Stellenbosch, South Africa, 19-26 January, pp 461-466.

Honma M, Shimomura T (1978). Metabolism of 1-amino-cyclopropane1-carboxylic acid. Agric. Biol. Chem. 42:1825-1831.

Jia YT, Ito H, Matsui H, Honma M (2000). 1-amino-cyclopropane-1carboxylate (ACC) deaminase induced by ACC synthesized and accumulated in Penicillium citrium intracellular spaces. Biosci. Biotechnol. Biochem. 64(2):299-305.

Logan DC, Stewart GR (1991). Role of ethylene in the germination of the hemiparasite Striga hermonthica. Plant Physiol. 97: 1435-1438.

Marley PS, Ahmed SM, Shebayan JAY, Lagoke STO (1999). Isolation of Fusarium oxysporum with potential for biocontrol of the witchweed 
(Striga hermonthica) in the Nigerian savanna. Biocontr. Sci. Tech. 9:159-163.

Moffett M.L, Giles JE, Wood BA (1983). Survival of Pseudomonas solanacearum biovars 2 and 3 in soil: effect of moisture and soil type. Soil Biol. Biochem 15:587-591.

Penrose DM, Glick BR (1997). Enzymes that regulate ethylene levels 1aminocyclopropane-1-carboxylic acid deaminase, ACC synthase and ACC oxidase. Indian J. Exp. Biol. 35(1):1-17.

Sato M, Urushizaki S, Nishiyama K, Sakai F, Ota Y (1987). Efficient production of ethylene by Pseudomonas syringae pv. Glycinea which causes Halo Blight in soyabeans. Agric. Biol. Chem. 51:11771178.

Savard ME, Miller JD, Ciotola M, Watson AK (1997). Secondary metabolites produced by a strain of Fusarium oxysporum used for Striga control in West Africa. Biocontr. Sci. Tech. 7:61-64.

Shah S, Li J, Moffatt BA, Glick BR (1997). ACC deaminase genes from plant growth-promoting bacteria. In: Ogoshi A, Kobayashi K, Hemma $\mathrm{Y}$, Kodema $\mathrm{F}$, Kondo N, Akino $\mathrm{S}$ (eds) Plant growth-promoting rhizobacteria: present status and future prospects: OECD, Paris, pp 320-324.
Shah S, Li J, Moffatt BA, Glick BR (1998). Isolation and characterization of ACC deaminase genes from two different plant growth-promoting rhizobacteria. Can. J. Microbiol. 44:833-843.

Sheehy RE, Honma M, Yamada M, Sasaki T, Martineau B, Hiatt WR (1991). Isolation, sequence, and expression in Escherichia coli of the Pseudomonas sp. Strain ACP gene encoding 1-aminocyclopropane-1-carboxylate deaminase. J. Bacteriol. 173:52605265.

Wang C, Knill E, Glick BR, Defago G (2000). Effect of transferring 1amino-cyclopropane-1-carboxylic acid (ACC) deaminase genes into Pseudomonas fluorescens strain $\mathrm{CHAO}$ and its gacA derivative CHA96 on their growth-promoting and disease-suppressive capabilities. Can. J. Microbiol. 46(10):898-907. 